\title{
Comparative Intercountry Analysis of Tertiarization as a Structural Component of Post-Industrial Development
}

\author{
${ }^{1}$ Elena V. Perepelkina, ${ }^{2}$ Vyacheslav A. Perepelkin, ${ }^{3}$ Dmitry V. Abramov, ${ }^{4}$ Victoria I. Vlezkova \\ 1,2,3,4 Samara State University of Economics, Samara, Russia \\ Email: saanecht@mail.ru,slavaap@rambler.ru,elena.perepelkina21@gmail.com
}

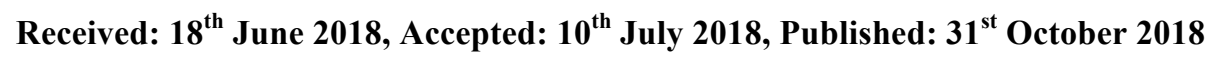

\begin{abstract}
The formation of postindustrial society actualizes the knowledge of economic patterns inherent in it, the most important of which is tertiarization. Its content includes both cross-sectoral shifts and qualitative changes in the structure of the tertiary sector. The object of the study is to identify general and specific features in increasing the share of the tertiary sector in the economy for groups of countries with different levels of socio-economic development. The reviewed statistics show that the share of the tertiary sector continues to grow in the world economy, with its highest rates in middle-income countries. The predominant income factor (on the side of demand) influences less than the potential factor (on the side of supply) of decreasing the share of the secondary sector and the factor of human capital. The authors emphasize specific factors for oil-exporting countries and post-socialist countries: the narrow sectoral economic spectrum and the priority development of material production. It has been established that the transformation of positive dynamics of the tertiary sector into a driver of sustainable growth of the entire economy is possible if there is a significant reserve of human capital and technological opportunities for replacing traditional services with impersonal production services with progressive labor productivity. If these resources are insufficient, traditional services dominate in the tertiary industry, whose positive impact on the growth of the tertiary sector and the entire economy is limited. Based on the intensive use of human capital, tertiarization is inherent and beneficial to developed countries. For the rest of the countries, the more positive results from the service expansion in production and consumption are, the greater their scale and demand for the expanded reproduction of human capital by the economy and society.
\end{abstract}

\section{Keywords}

Impersonal Services with Progressive Labor Productivity, Post-industrial Society, Services Sector, Tertiarization, Traditional Services, Human Capital.

\section{Introduction}

The structural aspect of post-industrial development, expressed in expansion of services in production and consumption, remains an important and promising direction of scientific research. In the course of economic development, at the national and global levels, the old reasons are weakened and new ones arise for a shift of economic activity from primary and secondary sectors to the tertiary one, which requires rethinking the content of this structural transformation. At the same time, the interest of scientists in this field has diminished recently, since a significant contribution to the development of the already existing concept of three-sectoral development of ClarkFisher economy (Clark, 1940, Fischer, 1939, Wolfe, 1955, Fourastie, 1954) seems unlikely. Moreover, in developed countries with a small aggregate share of primary and secondary sectors in the economy, the potential and growth rate of the share of the tertiary sector have decreased. We can also note specific country reasons for the insufficient study of tertiarization. So, in the post-Soviet space, the notion of the secondary activity in the tertiary industry has been preserved, as a result of which the term "tertiarization" (Perepelkin and Perepelkina, 2014), which is found in single publications, is about an increase in the share of the tertiary sector. This terminological difference seems not accidental, the signs of this difference are given in a brief review of the literature on relevant topics.

The works of Dietrich and Krüger (2010), following the concept of the economy division into primary, secondary and tertiary sectors, present an original mathematical model that takes into account the influence of general economic factors on inter-sectoral shifts. The results of the research show that the hierarchy of driving forces of the outstripping growth in the tertiary sector as a general trend of changes in the structure of the global economy varies from country to country. The dominant factors and results of the structural shift in favor of the tertiary sector can vary significantly, depending on the country's values of labor productivity, labor force qualifications, the value of the created social product, measured in statics and dynamics. In this connection, Souza, Bastos and Perobelli (2016) believe that genuine tertiarization takes place only in industrialized countries and relies on highly skilled labor capable to get a large added value. Sharing the above position, the authors have analyzed not only the share of the tertiary sector in 
gross value added, but have further studied qualitative changes that have taken place in the structure of the tertiary sector.

According to Jorgenson and Timmer (2011), and Vries (et al., 2012), tertiarization positively affects economic dynamics in developed countries, but the positive dynamics obtained should not be spread to other countries without regarding their socio-economic maturity. Rodrik (2016) believes that the excessive growth of the tertiary sector is dangerous for economies in developing countries due to premature de-industrialization coupled with the spread of parasitic services. Taking into account such threats, at the same time we note that the expansion of the tertiary sector increases employment due to greater labor intensity of production in it, improves the quality of life indicators due to education and healthcare growth, thereby it forms the basis for subsequent social and economic development.

Unlike representatives of the Anglo-Saxon economic school, German scientists allow limited state intervention in inter-sectoral structural changes (Grömling and Haß, 2009; Lautenbach, 2004). In particular, Hansen (2009), Heidling, Böhle and Habler (2010) focus on selective measures to ensure closer cooperation of commodity producing sectors with tertiary industries (based on the diffusion of knowledge intensive business services and service outsourcing), and Stampfl (2011) - focuses on consumption (through the expansion of sharing and pooling). In this context, it would be logical to single out a direction aimed at improving the structure of the tertiary sector within the structural policy of the state.

Human capital is the main resource of post-industrial society, which structural prerequisite is tertiarization. The presence of the latter in OECD countries has been empirically confirmed by the results of recent studies (Montresor and Marzetti 2011; Desmarchelier, Djellal and Gallouj 2013). Evangelista, Lucchese, and Meliciani (2013) argue that inter-sectoral shifts observed today are largely due to a faster increase in productivity and innovation of economic activities that are characterized by the active use of business services. In the case of knowledge intensive business services (KIBS), accumulation of physical capital is particularly widely replaced by generation and diffusion of human capital. Since the buyers of these services are representatives of all sectors, the worldwide expansion of KIBS is driven by growth drivers of the tertiary sector (Santos-Vijande, González-Mieres and López-Sánchez, 2013), and, according to Asikainen (2015), the economy in whole. Savona and Lorentz (2008) also believe that the dynamics of KIBS is one of the main reasons for tertiarization, which in turn depends on the intermediate demand for them throughout the economy. This increase in the tertiary sector is closely linked to a growth in commodity-producing sectors and will continue deepening the inter-sectoral division of labor, as well as progressive changes in services themselves. The KIBS example shows a positive overall economic effect strengthening positions of impersonal nearproduction services in the tertiary sector which illustrate improved characteristics in development and consumption. The problems of presented publications have determined the objectives of this research, the solution of which largely depends on possibilities of using specific methods and tools in it.

\section{Materials and Methods}

The theoretical basis for the study of the current economic stage in postindustrial society is Clark-Fisher model, according to which the economy is divided into three sectors: primary, exploiting natural resources; secondary, the core of which is industry; tertiary, specializing in tertiary services (Clark, 1940; Fischer, 1939). The quantitative description of the tertiary sector is consistent with the International Standard of Industrial Classification of All Economic Activities, adopted in its fourth edition (International Standard of Industrial Classification of All Economic Activities Revision 4 - ISIC Rev.4) (United Nations, 2008). The field of the study was determined by the requirements for studying the long-term socio-economic process at the global and national levels with the subsequent implementation of inter-country comparisons. Since the content of tertiarization far exceeds the scope of the subject of economic sciences, the authors abstracted from social, technical and other aspects of interdependence between the service expansion and human capital. Focusing on the economic component of this connection allows the authors to describe it, based on available information sources in the public domain.

Scientists distinguish sectoral tertiarization, quantitatively measured by the increase in the share of the tertiary sector in GDP and employment, and functional tertiarization, when the growth in the share of the tertiary sector is separately accounted for in accordance with the functional feature of the latter in all economic sectors, and then summarized for the economy as a whole. Due to the limited initial data for calculating the dynamics of functional tertiarization, sectoral tertiarization was evaluated.

The problem of comparability in temporal and spatial dimensions of statistical information in inter-country comparisons is diversified. In particular, these are features of the tertiary sector division by economic activities in different countries, the need to take into account the exchange rate relationships of currencies, bringing current prices to constant ones. The latter requires the use of price deflators, differentiated by economic activity, that is currently not feasible everywhere. At the same time, the difference between the nominal (measured in current prices) and the real (measured in constant prices) growth in production of the tertiary sector is very significant due to the backlog of the 
tertiary sector from secondary and primary sectors in terms of the average level of labor productivity. Also, there is no generally accepted method for estimating the value of human capital yet, either at individual or public levels. Estimates based on costs and revenues are divergent at times, so the use of mathematical methods is possible, but the results will also vary greatly.

For the reasons given, it is possible to expand the methods and depth of the quantitative analysis within the framework of panel research (Maroto-Sanchez, 2010), including those presented in the article, than comparisons of economic situations in the two countries popular in recent years (Souza, 2016).

\section{Results}

Expressing the main trend of structural transformation in modern economy, tertiarization (from the Latin word tertia the third) is studied in the context of the formation of postindustrial society that sets the goal to strengthen the humanitarian component. Such understanding of the role and place of tertiarization has become its definition as the process of transforming industrialized economy into the postindustrial one as the new economic and social structure of the society is formed, quantitatively expressed through the increase in the share of the total output of the tertiary sector with a sequential improvement in its composition.

Although only developed national economies are considered to be tertiarized ones, as early as 1970, the tertiary sector dominated value added (52\%) in the world economy as a whole. In 1995, the share of the tertiary sector in gross value added for the world economy reached $58.41 \%$, and in $2015-69.05 \%$ (Table 1)

\begin{tabular}{|c|c|c|c|c|c|c|}
\hline Year & $\begin{array}{c}\text { World } \\
\text { Economy (217 } \\
\text { Countries) }\end{array}$ & $\begin{array}{c}\text { High- Income } \\
\text { Countries (78 } \\
\text { Countries) }\end{array}$ & $\begin{array}{c}\text { Middle-Income } \\
\text { Countries (108 } \\
\text { Countries) }\end{array}$ & $\begin{array}{c}\text { Low-income } \\
\text { Countries (31 } \\
\text { Countries) }\end{array}$ & $\begin{array}{c}\text { OECD } \\
\text { Countries (35 } \\
\text { Countries) }\end{array}$ & $\begin{array}{c}\text { Underdeveloped } \\
\text { Countries (48 } \\
\text { Countries) }\end{array}$ \\
\hline 1995 & 58,059 & 69,094 & 46,757 & 41,408 & 69,12 & 41,835 \\
\hline 1996 & 58,236 & 69,33 & 46,591 & 41,36 & 69,37 & 41,332 \\
\hline 1997 & 62,8 & 69,451 & 47,597 & 40,32 & 69,44 & 41,362 \\
\hline 1998 & 63,627 & 70,065 & 49,988 & 42,392 & 69,991 & 42,816 \\
\hline 1999 & 64,106 & 70,478 & 49,54 & 42,79 & 70,494 & 41,229 \\
\hline 2000 & 64,172 & 70,483 & 49,639 & 45,218 & 70,535 & 41,685 \\
\hline 2001 & 65,167 & 71,401 & 50,863 & 45,283 & 71,461 & 42,749 \\
\hline 2002 & 65,732 & 72,121 & 51,085 & 45,45 & 72,204 & 45,556 \\
\hline 2003 & 65,758 & 72,208 & 50,8 & 45,708 & 72,336 & 46,347 \\
\hline 2004 & 65,358 & 72,027 & 50,059 & 45,734 & 72,16 & 46,392 \\
\hline 2005 & 65,422 & 72,06 & 50,195 & 45,923 & 72,264 & 46,489 \\
\hline 2006 & 65,4 & 72,885 & 50,538 & 45,903 & 72,057 & 46,631 \\
\hline 2007 & 65,756 & 71,887 & 51,213 & 46,75 & 72,06 & 47,019 \\
\hline 2008 & 66,028 & 72,308 & 51,09 & 46,128 & 72,519 & 46,561 \\
\hline 2009 & 67,86 & 74,062 & 53,075 & 45,988 & 74,182 & 47,47 \\
\hline 2010 & 67,266 & 73,35 & 52,76 & 47,3 & 73,651 & 47,8 \\
\hline 2011 & 67,072 & 73,158 & 52,55 & 46,987 & 73,489 & 47,447 \\
\hline 2012 & 67,565 & 73,402 & 53,663 & 46,459 & 73,722 & 48,4 \\
\hline 2013 & 67,829 & 73,411 & 54,551 & 47,582 & 73,735 & 48,992 \\
\hline 2014 & 68,254 & 73,702 & 55,539 & 47,746 & 73,91 & 48,391 \\
\hline 2015 & 69,046 & 74,2 & 57,073 & 48,131 & 74,222 & 49,813 \\
\hline 2016 & - & - & 57,807 & 48,089 & - & 49,738 \\
\hline
\end{tabular}

Source: Compiled by the authors according to the data from World Bank (2017b)

Table 1. The Share of the Tertiary Sector in Gross Value Added for the World Economy as a Whole and for Groups of Countries, \%

In the table, 217 countries of the world are grouped according to the income criterion and institutional criteria for the level of development, according to which developed countries belong to the Organization for Economic Cooperation and Development (OECD), the underdeveloped ones are defined according to the United Nations (UN) classification. The double number of countries in the high-income group compared to the OECD group, the one and a half times smaller number of countries in the low-income group than in the group of underdeveloped countries, did not lead to significant differences in the share of the tertiary sector in gross value added between these groups. The 
lower the level of development or income, the lower the representation of services in the economy is: in OECD countries or high-income countries, the average share of the tertiary sector, compared to underdeveloped countries and low-income countries, is more by a quarter than in middle-income countries - by $17 \%$. This illustrates the determining influence of income on the service expansion, the theoretical explanation of it is seen even from Engel's (1881) calculations on demand elasticity of household income for different product groups.

All time series of the share of the tertiary sector in the economy, represented in the table of the groups of countries, are characterized by a steady increase in the value of this indicator. For the period 1995-2015 it was the largest in the group of middle-income countries $(122.06 \%)$, covering half of the world's countries, and the lowest - in the group of high-income countries $(107.39 \%)$ and the OECD group of countries $(107.38 \%)$. This led to the fact that the gap in the share of the tertiary sector of middle-income countries from high-income countries decreased from $22 \%$ to $17 \%$ for the considered 21 years. The equal rate of growth in the share of the tertiary sector in the group of developed countries and the group of high-income countries indicates that it is weakly impacted by oil exporting countries in the latter group, although they differ in the reduced value of the indicator under consideration, but they are making efforts to increase it. In the group of low-income countries and in the group of underdeveloped countries, the tertiary sector expanded slightly more slowly than the global average $(116.2 \%$ and $119.1 \%$, respectively, versus $118.92 \%$ ), and it has lead to poverty and their insufficient technological development. It can be stated that the accelerated growth of the tertiary sector in the world economy was largely set by a group of middle-income countries, which, due to the relatively small share of this sector (11.97\% less than the world average), have a great potential and at the same time sufficient production and technological opportunities for the structural transformation of their economies in this direction.

The first positions in terms of the share of the tertiary sector in gross value added belonged to such small rich countries as Luxembourg (87.4\%), Cyprus (86.7\%), Malta (84.3\%), Saint Lucia (82.6\%). The size of these national economies predetermined their narrow specialization in financial and tourist services with a very limited presence of manufacturing industries. Tertiarization is the privilege of large countries with diversified economies, where each of the three sectors under consideration contributes significantly to the created gross product. The following places in the top ten most service-oriented economies of the world were occupied by the single developed countries: Lebanon (80.8), Great Britain (80.2\%), Greece (80.2\%), France (79.2\%), USA (78, 9\%), and the Netherlands (78.5\%).

In the world, the lowest share of the tertiary sector in gross value added was recorded in Puerto Rico (3.7\%), Libya (19.33), Papua New Guinea (23.33\%), Angola (26.96), Somalia 27.52), Turkmenistan (28.54\%), Sierra Leone (29.8\%), Chad (35.1\%), Mali (40.2\%), Niger (40.85\%). Based on gross national income (GNI) per capita, measured in US dollars at purchasing power parity (PPP) (World Bank, 2017a), these countries can be divided into two parts. The predominant part is characterized by a smaller factor than the average world level, which was $\$ 16,095$ in 2016 according to PPP. In Niger, GNI per capita was $\$ 970$ per person, in Sierra Leone \$1320, in Chad - \$1950, Mali - \$ 2040, Papua New Guinea \$2,700, in Sierra Leone - \$1,560, in Angola - \$ 6,220. Among these countries, the "richest" Angola has one of the lowest shares of the tertiary sector in the economy, and in the poorest Niger, where GNI per inhabitant is 6.4 times less than Angola's, the largest share of the tertiary sector (40.85\%). The smaller part of dozen outsiders in the world rating of service national economies is represented by those with a close or even higher level of GNI per inhabitant: Puerto Rico, Turkmenistan and Libya. And Puerto Rico, with a record low share of the tertiary sector (3.7\%), ranked last in this global ranking with a significant margin.

The analysis of these statistics shows that the level of income remains the most important one, but it is not always the dominant factor in the growth of the tertiary sector. The main feature of the economy of a particular country or a group of countries is able to give special power to acting factors on the supply side, as it happens with the group of leading oil exporting countries. The raw specialization of production and exports, as a rule, originating from the technological backwardness and weak provision of these countries with human capital, hinders the realization of opportunities to improve the economic structure. Theoretically, a significant expansion of the tertiary sector, based on a sufficiently high level of income of the population in many oil exporting countries, seems promising. However, in 2014 only Canada slightly surpassed (by 1.06\%) 15 leading countries in terms of oil exports and the average world share of the tertiary sector $(68.25 \%$ ) and the average share for this group of countries was about $50 \%$. Also, the reason for relatively low levels of the tertiary economy in economies of former "socialist" countries is the idea that the so-called "material production" is a priority in society. While the share of the tertiary sector in the world as a whole exceeded 69\%, in the largest countries of the post-Soviet space it is still much less: in 2016 in Russia it was $62.8 \%$, in Kazakhstan - 61.7\%, in Ukraine - 59 , 2\%, in Belarus - 56\% (World Bank 2017b).

The main obstacle to improve the structure of the tertiary sector by increasing the proportion of impersonal services that are characterized by a progressive increase in labor productivity when it is created (Desmarchelier, Dejellal and Gallouj 2013), even for OECD countries, is insufficiently available human capital in required specialization. The experience of tertiarization in economies of such "comparatively less developed" European countries as Greece, 
Portugal, and Spain illustrates the particular importance of upgrading labor force skills. The transfer of product, technological and organizational innovations in the tertiary sector from other countries, and then independent implementation requires accumulating a sufficient volume of human capital in the areas of modern professions (Teixeira and Fortuna, 2011; Silva, 2011). Getting rid of established interdependence between insufficiently high levels, taking into account modern requirements for conducting business activities in open markets on the one hand, and the vocational education and practical competencies of workers, technological parameters of existing and new productions on the other hand, means priority investment in main spheres generating human capital, such as education and science. Today, the potential for continuing rapid growth in tertiary economies is determined by the stock of human capital in the country, corresponding to the structural renewal task of the tertiary sector for the benefit of the entire economy (Duarte and Simöes 2014).

The production volumes increase slowly in traditional services (trade, hotel, catering, state and municipal management, social assistance), so labor productivity is low. The expansion of such low-skilled and lowproductivity activities in the tertiary sector lowers the aggregate productivity of labor without making more dynamic growth in either in the tertiary sector or the entire economy. The positive influence of the tertiary sector on the overall economic dynamics is especially small in the context of unconditional domination of traditional services over impersonal progressive services due to limited human capital, that's a negative notion of tertiarization often prevails in countries with a similar structure of the tertiary sector.

\section{Discussion}

Postindustrial society grows out of mature industrial society, while retaining strong manufacturing industries that feed raising tertiary industries by created goods and incomes. People confuse tertiarization with deindustrialization, because industrial and tertiary industries in the economy of the post-industrial society have mostly complementary rather than competing connections. The hybrid from material goods and services to improve existing or emerging new consumer properties in such products is an example of these connections.

For most countries in the world, it is statistically confirmed that even today changes in final demand remain the main factor in the service expansion. This applies primarily to educational, medical and social services, which are in demand in the context of human capital transformation into a key resource for economic development. For example, in Brazil, together with transportation, storage and communication services, as well as business services, they have formed an aggregate that has steadily increased in recent years at a rate higher than the average for the economy. At the same time, manufacturing industries demonstrated low and even negative growth rates (Souza et al. 2016, p. 143). However, in many OECD countries, tertiarization is influenced by such supply-side factors as cross-sectoral differences in the level of labor productivity and changes in demand for products and services (Maroto-Sanchez 2010), which is associated with the intensive use of highly skilled labor in the economy.

Depending on the group of services, the factor of different labor productivity acts differently. The share in the cost of the economic cumulative output of some traditional services, due to difficulties with the replacement of labor with capital, the use of technological advances in their creation and consequent lower productivity, increases mainly due to the effect of higher comparative prices for such services. On the contrary, the share of tertiary industries that actively use electronic information and communication technologies and highly skilled work is following the growth in "physical" results of their functioning due to the productivity progress. Changes in the demand for products and services are caused by changes in the division of labor between services and products, when the latter transfer part of previously independently performed service activities to specialized firms in the tertiary sector and, in addition, they order supplementary product services. Some scientists propose to consider intensive cooperation between complementary product sectors and the tertiary sector as another distinction between developed national economies from developing ones (Siddiqui and Salem 2010).

A high level of income of the population is a necessary, but not the only condition for owning a significant tertiary sector. The formation of the postindustrial economic structure is possible only on the basis of a mature competitive industry, the absence of which indicates the uncompleted stage of industrial development in the country. With the low level of economic diversification in many oil exporting countries, which is determined by the poor supply of qualified personnel in non-primary industries, there is no economically viable alternative to invest in oil production for a short-term perspective. With such a mono product, a poorly balanced economic structure, the tertiary sector is mainly represented by simple traditional services, the amount of demand for which is unstable due to their local sales and the income of consumers that regularly change along with oil prices. Nevertheless, even in such countries, the share of the tertiary sector in the economy is gradually growing, but from a relatively low base and with a slow pace.

The position of Baumol (1967) that specialization in services leads to a slowdown in economic growth is outdated. The tertiary sector is heterogeneous and includes traditional services characterized by the site of their production and 
modest saving capacity by production scale, low rates of productivity growth because it is difficult to rationalize their creation on modern technical and technological basis, the risk of provision of low - quality social services as a result of labor intensification. The scientific and technological achievements of recent decades have introduced easily and cheaply transported services with a significant potential to increase labor productivity, determined by good susceptibility of their industries to technological innovations (Kapur 2012). Such impersonal services with progressive labor productivity dynamics as electronic information and communication services and integrated part of business services depend on human capital, so education plays an important role in ensuring the growth of their supply (Peneder 2007; Peneder 2003). The expansion of modern impersonal progressive services in the tertiary sector positively affects labor productivity and the growth rate of advanced national economies. Along with this, the active use of new technologies in many services reduces the backlog of the tertiary sector in terms of the increase in labor productivity from productive sectors. Despite the leading role of labor costs in the cost of impersonal progressive services, especially in high-wage countries, relative prices for them are increasingly lower than those of primary and secondary sectors. In this connection, the opinion expressed by some scientists about the predominantly cost character of tertiarization of the created GDP structure and its absence measuring the "physical" volume of the product in the future may require revision due to the final loss of the evidence base.

Modern impersonal services are able to become a significant factor in economic growth, as many of their producers are able to benefit from technological advances, and they become more productive. According to Ghani (2010), first of all, producers of knowledge-intensive business services can take advantages of information and communication technologies, globalization and economies by production scale to increase productivity growth rates. The situation concerning education, health and culture services is ambiguous according to Pugno (2006). On the one hand, based on the level and dynamics of labor productivity, they are fairly characterized as stagnant. On the other hand, they make a decisive contribution to the formation of human capital, it is difficult to count on sustained economic growth under current conditions without having a significant reserve of human capital. The final evaluation of this socially important group of services should be given taking into account the synergetic effect of their spread across the economy. Pugno (2006) argues that its negative contribution to the overall increase in labor productivity of education, health and culture services is more offset by a positive impact on other aspects of accelerating economic growth and on the intangible component of the quality of life. This approach evaluating these services comes from the notion of economic growth and development as a result of synergy between new knowledge and human capital (Hanushek 2013).

\section{Conclusion}

In developed economies, terzirization is associated with a structural shift within the tertiary sector, aimed at increasing the share of impersonal services created by highly skilled and highly productive labor. A prerequisite for this is the active accumulation of human capital due to abundant investments in main sources of this economic resource - educational and scientific activities. In economies with an average or low level of development, the expansion of the tertiary sector first of all depends on the dynamics of the population's income, and only then on inter-sectoral differences in labor productivity and on strengthening of specialization in service activities. However, with a raw export orientation of the country's economy, the effect of financial security of households can cease to be decisive if the shortage of human capital does not allow investing in secondary and tertiary sectors.

The reason for the relatively small share of the tertiary sector may also be the tradition of underestimating its importance, inherited from the era of the "planned economy". The structural heterogeneity of national economies undergoing a systemic transformation predetermines diametrically opposite opinions concerning prospects for their change: "And processes of industrialization turned out to be incomplete, and post-industrial structures also did not receive serious development" (Suslov 2011, p. 102). The unilateral "new industrialization", aimed to correct mistakes of the past, can turn out to be a reversal of the general civilizational development. Tertiaryization is objectively necessary for building a postindustrial society, regardless of the specifics of the country, as it is obvious and expedient to make more active use of the growth potential of the national economy, associated with a smaller share of the tertiary sector in it compared to the world average.

The future is for economies benefiting from the results of educational and scientific activities carried out mainly in the tertiary sector, on which the intensity of the key resource accumulation of the postindustrial society - human capital depends. The accumulation of physical capital and the improvement of production programs in secondary and primary sectors are also relevant, since in case of their inconsistency with the created human capital, its application will not be effective. The problem of harmonizing the expanded reproduction of human capital with the needs of the economy in it can become an important part of upcoming structural studies. 


\section{References}

1. Clark, C.G.: The Conditions of Economic Progress. London: Macmillan (1940).

2. Fischer, A.G.B.: Production, Primary, Secondary and Tertiary. Economic Record. 15, 24-38 (1939).

3. Fourastie, J.: Die große Hoffnung des zwanzigsten Jahrhunderts. Köln-Deutz: Bund Verlag (1954).

4. Wolfe, M.: The Concept of Economic Sectors. Quarterly Journal of Economics. 69(3), 402-420 (1955).

5. Perepelkin, V.A., and Perepelkina, E.V.: The tertiarization of the world economy: theoretical and methodological and empirical analysis. Samara: PGSGA (2014).

6. Souza, K.B., Bastos, S.Q.A., Perobelli F.S.: Multiple trends of tertiarization: A comparative input-output analysis of the service sector expansion between Brazil and United States. EconomiA. 17(2), 141-158 (2016).

7. Dietrich, A., and Krüger, J.J.: Long-run sectoral development: Time-series evidence for the German economy. Structural Economic Dynamics. 21(2), 111-122 (2010).

8. Souza, K.B., Bastos, S.Q.A., Perobelli F.S.: Multiple trends of tertiarization: A comparative input-output analysis of the service sector expansion between Brazil and United States. EconomiA. 17(2), 141-158 (2016).

9. Jorgenson, D.W., Timmer, M.P.: Structural change in advanced nations a new set of stylized facts. Scandinavian Journal of Economics. 113(1), 1-29 (2011)

10. De Vries, G.J., Erumban, A.A., Timmer, M.P., Voskoboynikov, I., Wu, H.X.: Deconstructing the BRICs: Structural transformation and aggregate productivity growth. Journal of Comparative Economics. 40(2), 211227 (2012)

11. Rodrik, D.: Premature Deindustrialization. Journal Economic Growth. 21(1), 1-33 (2016)

12. Grömling, M., and Haß, H.-J.: Globale Megatrends und Perspektiven der deutschen Industrie. Köln: Deutscher Instituts-Verlag GmbH (2009)

13. Lautenbach, N.: Tertiarisierung und Informatisierung in Frankfurt am Main: Peter Lang (2004)

14. Hansen, H.: Grunderfolgs wissenintensiver Dienstleister.Wiesbaden: Gabler (2009)

15. Heidling, E., Böhle, F. and Habler, T.: Produktion mit Dienstleistung Integration als Zukunftschance. München und Mering:

Reiner Hampp Verlag (2010)

16. Stampfl, N.S.: Die Zukunft der Dienstleistungsökonomie. Momentaufnahme und Perspektiven. Berlin; Heidelberg: Springer-Verlag (2011)

17. Montresor, S., and Marzetti, G.V.: The deindustrialization/tertiarization hypothesis reconsidered: a subsystem application to the OECD7. Cambridge Journal of Economics. 35(2), 401-421 (2011)

18. Desmarchelier, B., Djellal, F. and Gallouj, F.: Knowledge intensive business services and long term growth. Structural Change and Economic Dynamics. 25, 188-205 (2012)

19. Evangelista, R., Lucchese, M., and Meliciani, V.: Business services, innovation and sectoral growth. Structural Change

Economic Dynamics. 25(S), 119-132 (2013)

20. Santos-Vijande, M.L., González-Mieres, C., and López-Sánchez J.A.: An assessment of innovativeness in KIBS: Implications on KIBS' co-creation culture, innovation capability, and performance. Journal of Business \& Industrial Marketing. 28(2), 86-102 (2013)

21. Asikainen, A-L.: Innovation modes and strategies in knowledge intensive business services. Service Business. 9(77), 77-95 (2015).

22. Savona, M., and Lorentz, A.: Evolutionary micro-dynamics and changes in the economic structure. Journal of Evolutionary Economics. 18(3-4), pp. 389-412 (2008).

23. Clark, C. G.: The Conditions of Economic Progress. London: Macmillan (1940).

24. Fischer, A.G.B.: Production, Primary, Secondary and Tertiary. Economic Record. 15, 24-38 (1939).

25. United Nations: International Standard Industrial Classification of All Economic Activities. Revision 4. United Nations Statistics Division. http://unstats.un.org/ unsd/cr/registry/isic-4.asp. Accessed 05 Jan. 2018 (2008)

26. Maroto-Sanchez, A.: Growth and productivity in the service sector: The state of the art. Institute of Social and Economic Analysis. Working Paper 07/2010. Madrid: Universidad de Alcala (2010)

27. Souza, K.B., Bastos, S.Q.A., Perobelli, F.S.: Multiple trends of tertiarization: A comparative input-output analysis of the service sector expansion between Brazil and United States. EconomiA. 17(2), 141-158 (2016).

28. World Bank: Services, etc., value added (\% of GDP). World Bank national accounts data, and OECD national accounts data files. http://data.worldbank.org/indicator/NV.SRV.TETC.ZS. Accessed 19 Jan. 2018 (2017a) 
29. Engel, E.: Des Rechnungsbuch der Hausfrau und seine Bedeutung im Wirtschaftsleben der Nation. Berlin: L. Simon (1881).

30. World Bank: Gross national income per capita 2016. Atlas method and PPP. World Development Indicators database. http://data.worldbank.org/data-catalog/GNI-per-capita-Atlas-and-PPP-table. Accessed 20 Jan. 2018 (2017b).

31. World Bank: Services, etc., value added (\% of GDP). World Bank national accounts data, and OECD national accounts data files. http://data.worldbank.org/indicator/NV.SRV.TETC.ZS. Accessed 19 Jan. 2018 (2017a).

32. Desmarchelier, B., Djellal, F. and Gallouj, F.: Knowledge intensive business services and long term growth. Structural Change and Economic Dynamics. 25, 188-205 (2012).

33. Teixeira, A.A.C., Fortuna, N.: Human capital, R\&D, trade, and long-run productivity. Testing the technological absorption hypothesis for the Portuguese economy, 1960-2001. Research Policy. 39(3), 335-350 (2011).

34. Silva, E.G.: Portugal and Spain: catching up and falling behind. A comparative analysis of productivity trends and their causes, 1980-2007. School of Economics and Management. Working Paper № 409. Porto: University of Porto (2011).

35. Duarte, A., Simöes, M.: Tertiarization and Human Capital. Do They Matter for Growth? Insights from Portugal. Scientific Annals of the Alexandru Ioan Cuza University of Iași Economic Sciences. 61(1), 30-53 (2014).

36. Souza, K.B., Bastos, S.Q.A., Perobelli F.S.: Multiple trends of tertiarization: A comparative input-output analysis of the service sector expansion between Brazil and United States. EconomiA. 17(2), 141-158 (2016).

37. Maroto-Sanchez, A.: Growth and productivity in the service sector: The state of the art. Institute of Social and Economic Analysis. Working Paper 07/2010. Madrid: Universidad de Alcala (2010).

38. Siddiqui, S.H., Salem, H.M.N.: Service-led industrial policy for inclusive growth and competitiveness. Competitiveness Review. 20(2), 166-181 (2010).

39. Baumol, W.J..: Macroeconomics of Unbalanced Growth: The Anatomy of Urban Crisis. American Economic Review. LVII(3), 415-426 (1967).

40. Kapur, B.K.: Progressive services, asymptotically stagnant services, and manufacturing: Growth and structural change. Journal of Economic Dynamics \& Control. 36, 1322-39 (2012).

41. Peneder, M.R.: A sectoral taxonomy of educational intensity. Empirica. 34, 189-212 (2007)

42. Peneder, M.R.: Industrial structure and aggregate growth. Structural Change and Economic Dynamics. 14(4), 427-448 (2003)

43. Ghani, E.: Is Service-Led Growth a Miracle for South Asia? In: Ghani, E. (ed.) The Service Revolution in South Asia. New York: Oxford University Press, pp. 28-61 (2010)

44. Pugno, M.: The service paradox and endogenous economic growth. Structural Change and Economic Dynamics. 17, pp. 99-115 (2006)

45. Pugno, M.: The service paradox and endogenous economic growth. Structural Change and Economic Dynamics. 17, pp. 99-115 (2006)

46. Hanushek, E.A.: Economic growth in developing countries: The role human capital. Economics of Education Review. 37, 204-121 (2013)

47. Suslov, N. I.: Do not reproduce the obsolete, but create a new one. ECO. 1, 102 (2011) 